3. Kacimon, O., ed. Bunchuk, B. I. 2010. Movoznavcha terminologiya u gramaty`kax S. Smal`Stocz kogo i F. G`artnera [Linguistic terminology in the grammars of S. Smal-Stotsky and F. Gartner]. Scientific Bulletin of Yuri Fedkovych National University of Chernivtsi. Slov'yans `ka filologiya. N. 496-497. Chernivci. Ruta, P. 47-60.

4. Macyuk, G. 2001. Preskry`pty`vne movoznavstvo v Galy`chy`ni (persha polovy`na XIX st.) [Prescriptive linguistics in Galicia (first half of the XIX century.)]. L`viv. Vy`davny`chy` $\mathrm{j}$ centr LNU im. Ivana Franka, P. 315-358.

5. Simovy`ch, V., ed. Tkach, L. 2005. Dekil`ka sliv pro nauku gramaty`ky` v nashy`x serednix shkolax ta pro pidruchny'k profesora Stocz'kogo i G’artnera "Ruska gramaty'ka" [A few words about the science of grammar in our secondary schools and the textbook of Professor Stotsky and Gartner "Ruska Gramatyka"]. Linguistics. Vol. 1. Chernivci. Kny`gy` XXI, P. 31-53.

6. Smal`Stocz`ky`j, S., G`artner, T. 1890. Pro plyan nauky` ruskoyi movy`v g imnaziyax [On the plan of Ruska language science in high schools], 8 p.

7. Tkach, L. 2009. Akademik Stepan Smal'-Stocz'ky’j. Do 150-richchya vid dnya narodzhennya [Academician Stepan Smal-Stotsky. To the 150th anniversary of his birth]. A miracle word. Ch. 1, P. 33-39.

8. Shevel`ov, Yu. 1998. Ukrayins `ka mova v pershij polovy`ni dvadcyatogo stolittya (19001941) [Ukrainian language in the first half of the twentieth century (1900-1941)]. Chernivci. "Ruta", P. 176-183.

У ДК 378.011.3-052:373.3.091.33:796(045)
DOI:10.31339/2617-0833-2020-1(28)-69-74

ФОРМУВАННЯ ГОТОВНОСТІ СТУДЕНТІВ ДО ВИКОРИСТАННЯ ТЕХНОЛОГІЇ ІГРОВОЇ ДІЯЛЬНОСТІ У ПРОЦЕСІ НАВЧАННЯ МОЛОДШИХ ШКОЛЯРІВ Кузьма-Качур М. І., Горват М. В., Кайс М. I.

\title{
THE FORMATION OF STUDENTS' READINESS FOR THE USAGE OF GAMING TECHNOLOGIES IN THE PROCESS OF TEACHING OF YOUNGER PUPILS
}

\author{
Kuzma-Kachur Mariia, Horvat Marianna, Kays Marina
}

У статті розкрито особливості підходу до вирішення проблеми формування готовності майбутніх вчителів щуодо застосування ігрової технологї на уроках $у$ початковій школі. 3'ясовано сутність ігрової технології та визначено перелік професійно важливих якостей педагога щзодо застосування дидактичних ігор. Запропоновано і описано модель формування готовності майбутніх учителів початкових класів до використання технологій ігрової діяльності в освітньому прочесі початкової школи.

Ключові слова: професійна підготовка, готовність, технологія ігрової діяльності, дидактична гра, компоненти готовності.

The article has dealed with the peculiarities of solving the problem of future teachers' willingness to use gaming technologies at the lessons in primary school. The authors have found out the sence of the gaming technology and determined the list of professionally important qualities of the teacher concerning the usage of didactic games. They have proposed and described a model of forming the readiness of future primary school teachers to use gaming technologies in the educational process of primary school. The authors have described the characteristics of motivational-purpose (reflects the orientation of the future teacher's personality to professional growth, substantiation of expediency aimed at the formation of competencies related to the use of gaming technologies in their pedagogical process), cognitive (provides students with knowledge of 
the sense and features of the gaming forms and methods under which the educational activities of younger students will take place, in the awareness of the need to create gaming situations at the lessons) and activity (involves the acquisition of future primary school teachers the ability to use in their professional work gaming forms and methods of educational and cognitive activity) components of the willingness of future primary school teachers to use gaming technologies at the lessons in elementary school.

Key words: professional training, readiness, technology of gaming activity, didactic game, components of readiness.

Однією 3 важливих проблем розвитку сучасного суспільства $\epsilon$ проблема вдосконалення освіти i виховання підростаючого покоління. Загальновідомо, що від характеру та змісту соціального замовлення, яке виконує освіта у сфері навчання і виховання людини, залежить майбутнє держави. Сучасне суспільство потребує особистість, здатну до творчості, ініціативи, саморозвитку, самоосвіти. Проблема $\epsilon$ цілком на часі у зв'язку 3 впровадженням у освітній процес Концепції Нової української школи, законів України «Про освіту», «Про вищу освіту», «Національної доктрини розвитку освіти України у XXI ст.» та ін. «За експертними оцінками, найбільш успішними на ринку праці в найближчій перспективі будуть фахівці, які вміють навчатися впродовж життя, критично мислити, ставити цілі та досягати їх, працювати в команді, спілкуватися в багатокультурному середовищі та володіти іншими сучасними вміннями» $[1$, с.4].

Останні зміни у системі освіти, трансформація поглядів на сучасного педагога, (пов'язані із впровадженням Державного стандарту початкової освіти 2018p.), акцентують увагу на необхідності формування творчої особистості, якій притаманні вміння приймати нестандартні рішення, здатність до самовиховання, саморозвитку та самовдосконалення, усвідомлення важливості саморозвитку у майбутній професійній педагогічній діяльності. У зв'язку з цим, вкрай необхідним є пошук нових підходів, які дозволяють досягти нової якості у дидактичній і методичній підготовці майбутнього вчителя початкової школи. Оволодіння здатністю використовувати елементи пошукових методів у професійній діяльності сприяє готовність майбутнього вчителя використовувати ігрові технології в освітньому процесі початкової школи. Проблема заслуговує на особливу увагу, оскільки головним завданням початкової освіти $\epsilon$ формування загально навчальних та предметних компетентностей, що $\epsilon$ невід'ємною складовою розвитку абстрактного і логічного мислення, а гра є основним видом діяльності дітей особливо в першому адаптаційно-ігровому циклі.

Розробці теоретико-методологічних засад моделювання ігрового навчального середовища приділяли увагу як педагоги-класики (П. Блонський, А. Макаренко, В. Сухомлинський, К. Ушинський та ін.) так і сучасні науковці (Ш. Амонашвілі, М. Марко, О. Савченко, Н. Ткаченко та ін.); психологічний вплив дидактичних ігор на пізнавальні здібності дитини досліджували Л. Виготський, Д. Ельконін, О. Леонтьєв, Ж. Піаже, С. Рубінштейн та ін.

Дидактичні аспекти застосування ігор у навчальному процесі вищої школи досліджувалися багатьма науковцями, серед яких: О. Вербицький, С. Вітвицька, М. Марко, А. Маркова, В. Пестряков, Н. Рибалко, М. Фомін, П. Щербань та ін. Згадані науковці сходяться на думці, що навчаючись у закладі вищої освіти, студент повинен мати можливість моделювати, опрацьовувати й закріплювати власні професійні навички і вміння.

Метою даної статті $\epsilon$ розкриття особливості підходу до вирішення проблеми формування готовності майбутніх вчителів до застосування ігрової технології на уроках у початковій школі.

Метою початкової освіти $є$ всебічний розвиток дитини, іiі талантів, здібностей, компетентностей та наскрізних умінь відповідно до вікових та індивідуальних психофізіологічних особливостей і потреб, формування цінностей, розвиток самостійності, творчості та допитливості [2]. Тут же зазначено перелік умінь для всіх ключових 
компетентностей: «читання 3 розумінням, уміння висловлювати власну думку усно i письмово, критичне та системне мислення, творчість, ініціативність, здатність логічно обгрунтовувати позицію, вміння конструктивно керувати емоціями, оцінювати ризики, приймати рішення, розв'язувати проблеми, співпрацювати з іншими особами».

Вступ до школи різко змінюе спосіб життя дитини, основним видом діяльності стає навчання. В Концепції Нової української школи враховано, складність різкого переходу дитини від відносно вільної діяльності (ігрової) до навчальної, яка носить обов'язковий характер. Враховано, що процес адаптації ускладнюється віковими особливостями молодшого школяра, які проявляються слабким переключенням уваги, нестійкістю пам'яті та мислення. Відповідно процес адаптації триває два роки (адаптаційно-ігровий цикл), яким передбачено враховувати вікові особливості розвитку та потреби дітей і дає можливість забезпечити подолання розбіжностей у досягненнях, зумовлених готовністю до здобуття освіти. Гра, ігрова діяльність залишається важливим засобом не лише відпочинку, а й творчого пізнання. Відтак, актуалізується проблема підготовки вчителів до впровадження навчально-ігрових технологій, які дозволяють докорінно змінити методологічні підходи до організації та здійсненню освітнього процесу в початковій школі.

Категорія «професійна підготовка» трактується науковцями відповідно до змісту їхніх досліджень. Як зазначають М. Кузьма-Качур та М. Горват «професійна підготовка вчителя $\epsilon$ складним, багатовекторним процесом. Він має кілька ступенів: молодший бакалавр, бакалавр, магістр» [3, с.86].

На кожному 3 цих етапів студенти оволодівають системою знань, професійних навичок і умінь серед яких можемо виділити готовність майбутніх учителів до застосування технологій ігрової діяльності в освітньому процесі початкової школи. Технологію ігрової діяльності розглядають як системний засіб організації навчання, спрямований на оптимальну побудову навчально-виховного процесу та реалізацію його завдань. Він заснований на діяльнісному підході, що забезпечує школяреві позицію суб'єкта власного учіння, інтенсифікацію пізнавальної діяльності, генералізацію знань і вмінь учнів 3 метою використання їх у нестандартних умовах [4, с. 247].

Результати констатувального експерименту, проведеного на базі Мукачівського державного університету, стали основою створення моделі готовності студентів доастосування ігрових технологій у початковій школі (Рис.1). Модель формування готовності майбутніх учителів початкових класів до застосування технологій ігрової діяльності побудована $з$ урахуванням того, що вона $є$ окремим компонентом більш широкої системи професійної підготовки вчителів за спеціальністю 013 «Початкова освіта». Тому, спроектовані компоненти формування у студентів готовності до застосування технологій ігрової діяльності спрямовані як на розвиток загальноосвітніх складових змісту, так і на формування професійно-орієнтованих видів діяльності: мотиваційно-цільовий, когнітивний, діяльнісний.

Зміст мотиваційно-цільового компонента відображає направленість особистості майбутнього вчителя на професійне зростання, обгрунтуванні доцільності, спрямованої на формування компетентностей, пов'язаних із застосуванням ігрових технологій у своїй педагогічній діяльності. 


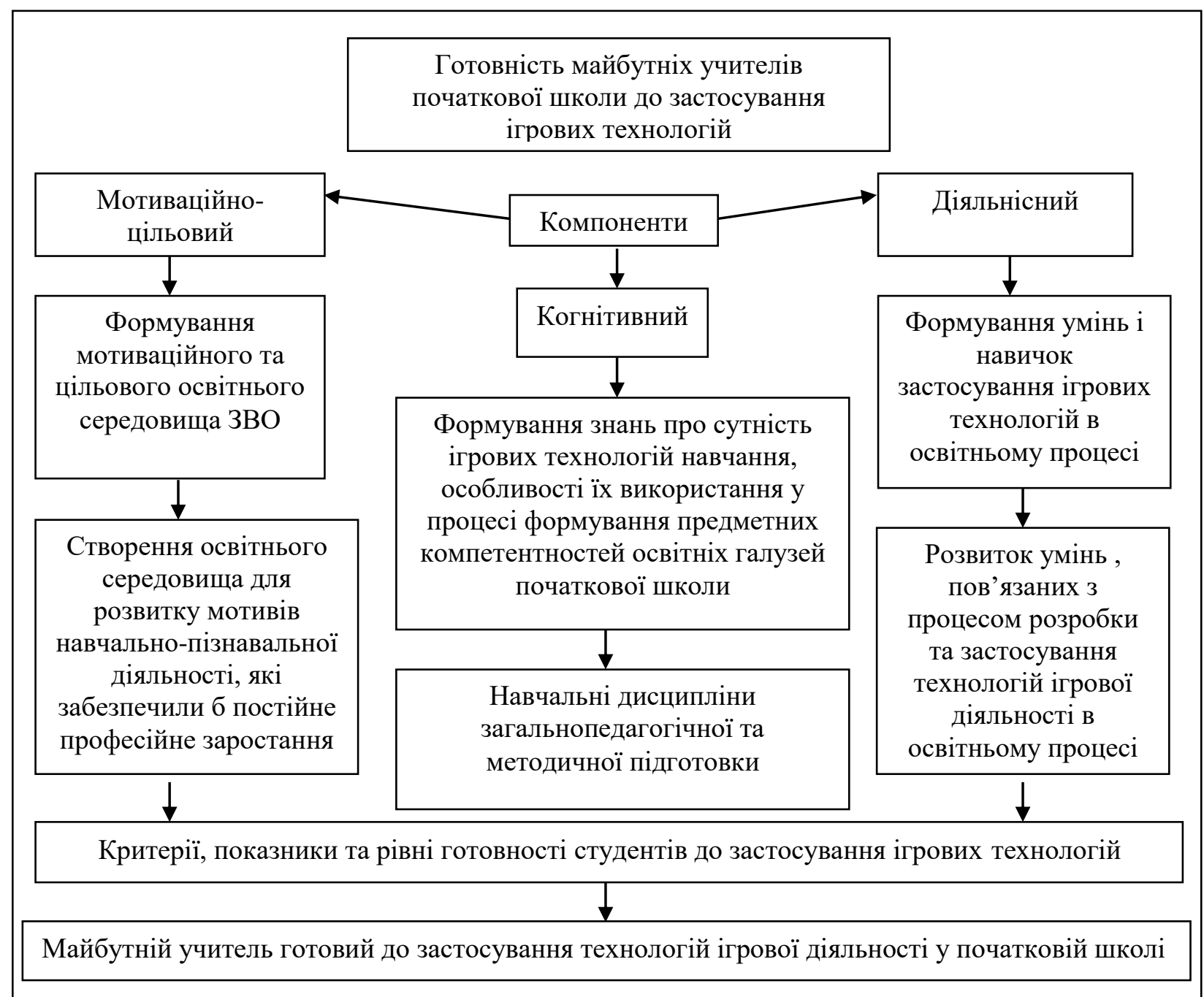

\section{Рис.1. Модель готовності студентів до застосування технологій ігрової діяльності в освітньому процесі початкової школи}

Когнітивний компонент передбачає оволодіння студентами знань про сутність та особливості ігрових форм i методів, за яких відбуватиметься навчально-пізнавальна діяльність молодших школярів, в усвідомленні необхідності створення ігрових ситуацій на уроках. Цьому сприяють навчальні дисципліни загальнопедагогічної та методичної підготовки: «Технології навчання освітніх галузей початкової школи», «Технології навчання освітньої галузі «Математика», «Технології навчання освітніх галузей «Природознавство», «Суспільствознавство» та ін.

Діяльнісний компонент передбачає набуття у майбутніх вчителів початкових класів умінь застосовувати у своїй професійній роботі ігрові форми і методи навчально-пізнавальної діяльності. Наявність цього компонента в структурі готовності студентів до застосування ігрових технологій при вивченні предметів освітніх галузей початкової школи дозволяє підвищити професійний потенціал майбутнього вчителя. Найбільше означений компонент зреалізовується студентами під час педагогічних практик.

У зв'язку з викладеним вище виділимо складові готовності вчителя до застосування в освітньому процесі початкової школи технологій ігрової діяльності:

- професійна компетентність (акумуляція знань 3 теорії і методики застосування ігрових технологій в освітньому процесі початкової школи);

- операційно-технічна готовність до застосування ігрових технологій;

- творча активність та високий рівень інформаційної культури; 
- уміння враховувати психолого-педагогічні особливості молодших школярів під час застосування ігрових технологій в процесі навчання.

Готовність майбутніх учителів до застосування технологій ігрової діяльності залежить і від досвіду такої діяльності, набутого під час навчання у ЗВО. Головною метою навчальних ігор, що проводяться під час аудиторних занять $\epsilon$ формування в майбутніх учителів початкової школи уміння поєднувати набуті теоретичні знання 3 практичною діяльністю. Оволодіти необхідними вміннями і навичками з організації ігрової діяльності студент зможе лише тоді, коли сам достатньою мірою виявлятиме до них інтерес і докладатиме певних зусиль. У процесі становлення фахівця ігрова діяльність виконує такі функції: спонукальну (викликає інтерес у студентів до означеного виду діяльності); комунікабельну (формує вміння культури спілкування майбутніх учителів початкової школи); самореалізації (кожен учасник гри реалізує свої можливості у відповідності до набутих знань, умінь та особистісних якостей); розвивальну (розвиток уваги, волі та інших психічних якостей); діагностичну (виявлення прогалин у знаннях, недосконале володіння уміннями та навичками); корекційну (внесення позитивних змін у структуру формування особистості майбутніх педагогів).

На підставі теоретичних узагальнень 3 досліджуваної проблеми можна зробити такі висновки: професійний розвиток майбутнього вчителя початкової школи забезпечується ігровими педагогічними технологіями, в основі яких гра розглядається як вид діяльності студентів. Використання різноманітних ігрових педагогічних технологій для подальшого професійного саморозвитку у навчально-професійній діяльності, не тільки адаптують студентів до особливостей подальшої педагогічної діяльності, але й надають можливість самостійно добирати варіанти ігрових технологій, які будуть ефективними для вирішення конкретних завдань.

Перспективи подальших наших пошуків пов'язані з розробкою ігрових педагогічних технологій, які сприятимуть професійному саморозвитку майбутнього вчителя початкової школи.

\section{Список використаних джерел}

1. Нова українська школа. Порадник для вчителя. [Електронний ресурс]. - Режим доступу: http://nus.org.ua/wp-content/uploads/2017/11/NUSH-poradnyk-dlya-vchytelya.pdf

2. Державний стандарт початкової освіти (2018p.) [Електронний ресурс]. - Режим доступу:http://nus.org.ua/news/uryad-opublikuvav-novyj-derzhstandart-pochatkovoyiosvity-dokument/.

3. Кузьма-Качур М.I. Підготовка майбутнього вчителя початкової школи до суб'єктсуб’єктної взаємодії з учнями на уроках природознавства / M.I. Кузьма-Качур, М.В. Горват // Науковий вісник: збірник наукових праць Мукачівського державного університету. Серія «Педагогіка та психологія. - Мукачево, 2016. - Вип.2 (4). - С.8588.

4. Ткаченко Н.В. Формування готовності студентів до використання технології ігрової діяльності у процесі навчання математики в початковій школі /Н.В. Ткаченко //Вісник Чернігівського національного педагогічного університету. Серія : Педагогічні науки. 2015. - Вип. 125. - С. $246-251$.

\section{References}

1. Nova ukrayins'ka shkola. Poradnyk dlya vchytelya [New Ukrainian School. Teacher's Guide]. Available at: http://nus.org.ua/wp-content/uploads/2017/11/NUSH-poradnyk-dlyavchytelya.pdf.

2. Derzhavnyi standart pochatkovoi osvity [State standard of primary education].- Available at:http://nus.org.ua/news/uryad-opublikuvav-novyj-derzhstandart-pochatkovoyi-osvitydokument/. 
3. Kuz'ma-Kachur, M.I. and Horvat, M.V. (2016), Pidhotovka maybutn'oho vchytelya pochatkovoyi shkoly do sub'yekt-sub'yektnoyi vzayemodiyi z uchnyamy na urokakh pryrodoznavstva [Preparing a future elementary school teacher for subject-subject interaction with students in science lessons]. Scientific Bulletin of Mukachevo State University. Series: Pedagogy and Psychology, 2 (4), pp. 85-88.

4. Tkachenko, N.V. (2015), Formuvannya hotovnosti studentiv do vykorystannya tekhnolohiyi ihrovoyi diyal'nosti u protsesi navchannya matematyky $\mathrm{v}$ pochatkoviy shkoli [Formation of students' readiness to use technology of play activity in the process of teaching mathematics in elementary school]. Bulletin of Chernihiv National Pedagogical University. Series: Pedagogical Sciences, 125, pp. 246-251.

УДК 37.022:372.8

DOI:10.31339/2617-0833-2020-1(28)-74-78

\section{ФОРМУВАННЯ ПРЕДМЕТНОЇ КОМПЕТЕНТНОСТІ МАЙБУТНІХ УЧИТЕЛІВ ПОЧАТКОВОЇ ШКОЛИ З АНАТОМІї ТА ФІЗІОЛОГІї ЛЮДИНИ: ЗАГАЛЬНІ ПІДХОДИ}

Кузьма-Качур М. І., Горват М. В., Шелельо А. В.

\section{FUTURE PRIMARY SCHOOL TEACHERS' SUBJECT COMPETENCE FORMATION IN THE HUMAN ANATOMY AND PHYSIOLOGY: GENERAL APPROACHES}

Kuzma-Kachur Mariia, Horvat Marianna, Shelelo Antonina

У статті наведено теоретичні питання щзодо формування предметноі компетентності майбутніх учителів початкових класів із анатомії та фізіології людини. Авторами обтрунтовано сучасні підходи до формування предметної компетентності майбутніх учителів із анатомії та фізіологї людини в процесі професійної підготовки: системний, синергетичний, компетентнісний та діяльнісний.

Ключові слова: професійна підготовка, компетентності з анатомії та фізіології людини майбутнього вчителя початкової школи.

The article deals with theoretical questions concerning the future primary school teachers' subject competence in human anatomy and physiology formation. The authors substantiate modern approaches of future teachers' subject competence formation in the human anatomy and physiology in the process of vocational training: systemic, synergistic, competent and active.

Key words: vocational training, the future primary school teacher's competences in human anatomy and physiology

Серед провідних напрямів державної політики та відповідно до Національної стратегії розвитку освіти в Україні (на період до 2021 р.), Закону «Про освіту» (2017), Концепції Нової української школи визначено забезпечення підтримки здоров'я та поширення здорового способу життя шляхом модернізації структури, змісту у організації освітнього процесу на засадах компетентнісного підходу. Концепція Нової української школи спрямована на формування загально навчальних та предметних компетентностей молодших школярів. Нові вимоги до випускника, майбутнього вчителя початкової школи, вимагають оновлення методик, диференційованого підходу у визначенні мінімальних, достатніх і спеціальних грунтовних знань та умінь з освітніх галузей. Тому проблема підготовки вчителя нової генерації, який повинен бути творчою особистістю, здатною до самонавчання упродовж життя, самовдосконалення і саморозвитку; який постійно шукає, аналізує, апробує раціональніші шляхи, умови, методи, засоби, форми ефективного вирішення конкретних 